\title{
PERBEDAAN JARAK TANAM \\ TERHADAP PRODUKTIVITAS DEFOLIASI PERTAMA \\ RUMPUT MOTT (Pennisetum purpureum cv. Mott)
}

\author{
Nur Istikomah ${ }^{*}$ dan Agustina Widyasworo Kunharjanti**) \\ ${ }^{*}$ Program Studi Ilmu Ternak \\ **) Dosen Pembimbing Program Studi Ilmu Ternak \\ Fakultas Peternakan Universitas Islam Balitar
}

\begin{abstract}
The research was conducted in Sumber Sumber Village of Sanankulon District of Blitar, during April 22 to June 16, 2017.The trial used 10 Mott grass poles on each plot with different spacing ie, $\mathrm{P} 0=50 \times 100 \mathrm{~cm}, \mathrm{P} 1=75 \times 100 \mathrm{~cm}, \mathrm{P} 2=100 \times 100 \mathrm{~cm}$ and $\mathrm{P} 3=125 \mathrm{x}$ $100 \mathrm{~cm}$. Parameters measured were number of tillers, plant height, leaf length, leaf width, fresh weight and leaf green index. The design used was a complete randomized design (Gazpers, 1991) consisting of 4 treatments of 6 replications. The result of variance showed that the difference of plant spacing had no significant effect $(p>0,05)$ on productivity including number of tiller, plant height, leaf width, leaf length, fresh weight of green leaf index. Based on the results of research on differences in spacing to the productivity of first defoliation Mott grass then Need further research on the effect of cropping methods on grass growth and productivity.
\end{abstract}

Keywords: plant spacing, Mott grass, productivity.

\section{PENDAHULUAN}

Kebutuhan masyarakat Indonesia akan protein hewani semakin meningkat. Untuk memenuhi kebutuhan tersebut, harus diimbangi dengan peningkatan produk yang dihasilkan oleh ternak. Peningkatan produksi ternak perlu didukung oleh pembibitan, tatalaksana pemeliharaan serta pemberian makanan yang baik (Paat dan Luice, 2012).

Dalam dunia peternakan, pakan ternak merupakan faktor yang sangat menentukan berhasil tidaknya suatu usaha peternakan. Hal ini dikarenakan $60-80 \%$ biaya produksi dalam dunia peternakan tertanam pada sektor makanan. Hijauan merupakan sumber pakan utama bagi ternak ruminansia, baik untuk hidup pokok, pertumbuhan, produksi dan reproduksinya. Hijauan memiliki peranan yang sangat penting, karena hijauan mengandung zat makanan yang dibutuhkan oleh ternak ruminansia, sehingga untuk mencapai produktivitas yang optimal harus ditunjang dengan peningkatan penyediaan hijauan pakan yang cukup baik kuantitas, kualitas maupun kontinuitasnya (Muhakka dan Rosa, 2012).

Ketersediaan hijauan merupakan faktor yang penting dalam menentukan keberhasilan usaha peternakan ternak ruminansia. Hal ini dikarenakan hampir $90 \%$ pakan ternak ruminansia berasal dari hijauan dengan konsumsi segar perhari $10-15 \%$ dari berat badan,sedangkan sisanya adalah konsentrat dan pakan tambahan (Seseray, Budi dan Marlin, 2013).

Rumput Mott (Pennisetum purpureum cv. Mott) merupakan salah satu hijauan pakan ternak yang hingga saat ini banyak diusahakan secara intensif dalam usaha peternakan ruminansia. Hal ini cukup beralasan karena rumput Mott dapat menghasilkan produksi tinggi, kualitas baik dan daya adaptasi terhadap lingkungan yang cukup baik (Sandiah, Yulius dan La Ode, 2011). 
Dalam proses jarak tanam yang tepat tidak hanya menghasilkan pertumbuhan dan jumlah anakan yang optimum, tetapi juga akan memberikan hasil yang optimum. Menurut Hatta (2011) jarak tanam yang tepat akan memberikan pertumbuhan bagian atas tanaman yang baik sehingga dapat memanfaatkan lebih banyak cahaya matahari dan pertumbuhan bagian bawah tanaman yang juga baik karena memperoleh lebih banyak unsur hara. Sebaliknya, jarak tanam yang terlalu rapat akan mengakibatkan terjadinya kompetisi antara tanaman sangat ketat dalam memperoleh sinar matahari, air, dan unsur hara. Akibatnya pertumbuhan tanaman terhambat dan hasil produksi pada tanaman rendah.

Menurut Sirait, Tarigan dan Simanihuruk (2015) pengaturan jarak tanam dalam pembudidayaan hijauan makanan ternak memungkinkan produktivitas hijauan yang lebih optimal sehingga ketersediaan pakan baik dari segi kualitas maupun kuantitas dapat terpenuhi dan tersedia sepanjang tahun. Berkaitan dengan latar belakang yang dikemukakan perlu dilakukan penelitian mengenai Perbedaan Jarak Tanam Terhadap Produktivitas Defoliasi Pertama Rumput Mott (Pennisetum purpureum cv. Mott).

Rumput Mott (Pennisetum purpureum cv. Mott) merupakan salah satu jenis hijauan pakan ternak berkualitas dan disukai ternak. Rumput ini dapat hidup di berbagai tempat, responsif terhadap pemupukan, serta menghendaki tingkat kesuburan tanah yang tinggi. Rumput Mott tumbuh dan terus menerus tumbuh berproduksi menghasilkan anakan apabila dipangkas secara teratur (Sirait, Tarigan dan Simanihuruk, 2015).

Rumput Mott dibudidayakan dengan potongan batang atau sobekan rumpun sebagai bibit. Bahan stek berasal dari batang yang sehat dan tua, panjang stek $20-25 \mathrm{~cm}, 2-3$ ruas. Waktu terbaik untuk memanen rumput adalah pada fase vegetatif sebelum pembentukan bunga (Thallib,2016).

Rumput Mott memiliki batang yang pendek dan lunak sehingga memudahkan dalam pemotongan. Jarak antar ruas $1-4 \mathrm{~cm}$, sedangkan pada jenis rumput lain seperti King Grass dapat mencapai $10-12 \mathrm{~cm}$. Rumput Mott memiliki tinggi sekitar 44,2 - 74,9 cm (Sulistya dan Mariyono, 2013).

Jumlah tanaman per hektar merupakan faktor penting untuk mendapatkan hasil maksimal. Produksi maksimal dicapai bila menggunakan jarak tanam yang sesuai. Semakin tinggi tingkat kerapatan suatu tanaman mengakibatkan semakin ketat persaingan tanaman dalam hal mendapatkan unsur hara dan cahaya.

Jarak tanam mempengaruhi tinggi rendahnya hasil tanaman, sehingga tinggi rendahnya hasil tanaman mempengaruhi produksi dalam satu areal. Peningkatan produksi diawali oleh meningkatnya hasil per satuan luas, kemudian setelah titik maksimum tercapai hasil akan menurun. Diduga jarak tanam mempengaruhi ketersediaan unsur hara bagi tanaman yang berperan dalam proses pertumbuhan dan perkembangan tanaman sehingga juga akan berpengaruh terhadap berat segar tanaman. Sari (2012) menyatakan produksi rumput dipengaruhi pertambahan tinggi dan jumlah anakan yang dihasilkan. Hal ini berbeda dengan pendapat Cristianto dan Agung (2014) menyatakan bahwa tingginya hasil per satuan luas tidak secara nyata didukung oleh pertumbuhan vegetatif tanaman. Banyaknya jumlah anakan tidak selalu menghasilkan produksi berat segar yang optimal.

Menurut Nurlaili (2010), jarak tanam mempengaruhi populasi tanaman dan koefisien penggunaan cahaya, mempengaruhi kompetisi antara tanaman dalam menggunakan air dan zat hara, sehingga pada ahirnya akan mempengaruhi hasil produksi tanaman tersebut.

Kerapatan tanaman mempengaruhi penampilan dan produksi tanaman, terutama karena koefisien penggunaan cahaya. Penampilan masing-masing tanaman secara individu dapat menurun karena persaingan untuk memperoleh cahaya dan faktor pertumbuhan lain. Tanaman 
memberikan respon dengan mengurangi ukuran baik pada seluruh tanaman maupun pada bagian tertentu.

Salah satu hal yang dapat dilakukan untuk meningkatkan produksi Rumput Mott adalah dengan mengatur kerapatan tanaman persatuan luas. Penambahan jumlah tanaman akan menurunkan hasil karena terjadi kompetisi hara, air, radiasi matahari dan ruang tumbuh. Secara umum ada dua tipe jarak tanam yang banyak dipraktekkan, yaitu segi empat dan persegi panjang.

\section{MATERI DAN METODE PENELITIAN}

\section{Lokasi dan Waktu Penelitian}

Penelitian ini dilakukan di Desa Sumber Kecamatan Sanankulon Kabupaten Blitar. Waktu yang diperlukan untuk melakukan penelitian selama dua bulan yang dimulai tanggal 22 April hingga 16 Juni 2017.

\section{Materi Penelitian}

Penelitian ini menggunakan alat seperti cangkul, sabit, meteran, tali, timbangan, dan Bagan Warna Daun. Materi yang digunakan untuk penelitian adalah spesies rumput Mott,air, tanah, dan pupuk.

\section{Metode Penelitian}

Metode penelitian dilakukan secara eksperimen yaitu dengan melakukan percobaan variasi jarak pada penanaman hijauan pakan ternak yaitu rumput Mott. Rancangan yang digunakan adalah Rancangan Acak Lengkap (RAL) dengan 4 perlakuan dan 6 ulangan. Dalam satu petak terdiri atas 10 tanaman dengan luasan berbeda pada setiap perlakuan.

Perlakuan yang digunakan dalam penelitian adalah sebagai berikut:

$\mathrm{P} 0$ : penanaman rumput Mott dengan jarak tanam $50 \times 100 \mathrm{~cm}$

$\mathrm{P} 2$ : penanaman rumput Mott dengan jarak tanam $75 \times 100 \mathrm{~cm}$

P3 : penanaman rumput Mott dengan jarak tanam $100 \times 100 \mathrm{~cm}$

P4 : penanaman rumput Mott dengan jarak tanam 125 x $100 \mathrm{~cm}$

\section{Prosedur Penelitian}

\section{a. Pengolahan Lahan}

Tanah pada lahan tanam dibersihkan terlebih dahulu dari rumput atau tanaman liar. Setelah lahan bersih dilakukan penggemburan dengan cara dibajak, dan diratakan kembali.

b. Pembuatan Guludan

Pembuatan guludan dapat disesuaikan dengan jenis rumput gajah yang dibudidayakan, tergantung dengan kebutuhan jarak tanam yang diinginkan.

c. Penanaman

Penanaman menggunakan sobekan rumpun (pols). Pemelihan bibit harus dipilih batang yang tua dengan jumlah mata ruas 2 - 3 buah. Penanaman dilakukan posisi miring 30 derajat mengarah kea arah matahari.

d. Pemupukan

Proses pemupukan dilakukan pada tanaman yang telah berumur 2 minggu setelah penanaman.

e. Pemanenan

Rumput Mott dipanen pada umur 55 hari. Pemotongan dilakukan pada ruas batang terbawah dengan menyisakan batang sepanjang $5-10 \mathrm{~cm}$.

\section{Variabel Pengamatan}

Adapun variabel yang diamati meliputi:

a. Jumlah anakan, dihitung pada tanaman yang telah mempunyai anakan yang telah mempunyai daun dan terbuka sempurna. 
b. Tinggi tanaman, diukur dari pangkal batang (permukaan tanah) sampai bagian tertinggi dinyatakan dalam satuan $\mathrm{cm}$.

c. Panjang daun, diukur pada daun semua daun mulai dari pangkal sampai ujung daun dan dinyatakan dalam satuan $\mathrm{cm}$.

d. Lebar daun, diukur pada bagian tengah daun yang terlebar dan dinyatakan dalam satuan $\mathrm{cm}$.

e. Berat segar, diukur pada semua tanaman per rumpun pada saat panen dan dinyatakan dalam satuan gram.

\section{Analisa Data}

Data yang diperoleh dari penelitian ini dianalisis menggunanakan metode percobaan Rancangan Acak Lengkap apabila terdapat perbedaan pengaruh yang nyata atau sangat nyata dilanjutkan dengan Uji Jarak Berganda Duncan (UJBD). Model percobaan matematika yang digunakan (Gazperzs 1991)

\section{HASIL DAN PEMBAHASAN Jumlah anakan}

Jumlah anakan merupakan salah satu bagian yang menunjukkan pertumbuhan dan perkembangan tanaman pada fase vegetatif. Jumlah anakan juga ikut menentukan tinggi rendahnya bobot hijauan yang dihasilkan. Jumlah anakan yang dimaksud adalah semua tunas tanaman yang sudah memiliki daun dan muncul dari tanah pada rumpun bukan cabang yang muncul dari buku atau ruas. Jumlah anakan rumput Mott pada defoliasi pertama disajikan dalam tabel 1 .

Tabel 1. Rata-rata Jumlah Anakan (batang/rumpun) rumput Mott

No Perlakuan Jumlah anakan

\begin{tabular}{lll}
\hline 1 & P0 & $9,1^{\mathrm{a}}$ \\
2 & P1 & $9,7^{\mathrm{a}}$ \\
3 & P2 & $10^{\mathrm{a}}$ \\
4 & P3 & $9,8^{\mathrm{a}}$
\end{tabular}

Keterangan ; angka dengan superskrip huruf berbeda pada kolom yang sama menunjukkan perbedaan yang nyata $(\mathrm{p}<0,05)$

Hasil penelitian menunjukkan rata-rata jumlah anakan rumput Mott tertinggi pada $\mathrm{P} 2=$ 100 x $100 \mathrm{~cm}$ sebanyak 10 batang anakan, kemudian diikuti oleh P3 = 125 x $100 \mathrm{~cm}$ sebanyak 9,8 anakan; $\mathrm{P} 1=75 \times 100 \mathrm{~cm} \mathrm{9,7}$ anakan dan $\mathrm{P} 0=50 \times 100 \mathrm{~cm}$ dengan produksi terendah yaitu 9,1 anakan. Hasil statistik memperlihatkan bahwa rataan jumlah anakan yang dihasilkan dalam penelitian ini lebih rendah dibandingkan dengan hasil yang dicapai oleh penelitian lain. Kisaran jumlah anakan yang dihasilkan dalam penelitian ini adalah $9-10$ batang anakan. Hal ini berbeda dengan Taulu dan Paulus (2012) yang menyatakan dalam penelitiannya jumlah anakan yang dihasilkan sebanyak 12 batang anakan. Sirait, Tarigan dan Simanihuruk (2015) juga menambahakan bahwa jumlah anakan yang dihasilkkan dari penelitiannya sebanyak 33 anakan. Sehingga jumlah anakan yang dihasilkan dalam penelitian ini masih lebih rendah. Hasil penelitian menunjukkan bahwa secara statistik perlakuan jarak tanam tidak berpengaruh nyata $(\mathrm{P}>0,05)$ terhadap jumlah anakan rumput Mott.

Hasil jumlah anakan yang diperoleh dalam penelitian ini tidak sesuai dengan pernyataan Khakim, Muhammad (2017) bahwa pada tumbuhan dengan jarak tanam yang 
lebih lebar memungkinkan pembentukan anakan lebih banyak dibandingkan dengan jarak tanam yang lebih sempit karena tingkat kompetisi hara dan air lebih kecil.

Diduga rata-rata jumlah anakan terhadap antarperlakuan yang relatif sama tersebut disebabkan oleh faktor unsur hara yang ada di dalam tanah masih lebih dari cukup untuk memenuhi kebutuhan tanaman. Hal ini didukung pendapat Sandiah (2011) yang menyatakan bahwa pertumbuhan tanaman sangat dipengaruhi oleh ketersediaan unsur hara dalam tanah. Kebutuhan tanaman terhadap hara seperti nitrogen $(\mathrm{N})$ diduga masih tersedia dalam jumlah yang cukup sehingga nutrisi yang diserap rumput Mott masih dapat digunakan untuk tumbuh dan berkembang, sehingga perbedaan perlakuan tidak menyebabkan perbedaan signifikan hingga masa pemanenan.

\section{Tinggi tanaman}

Tinggi tanaman merupakan salah satu indikator untuk mengukur produktivitas tanaman. Tinggi tanaman dapat menentukan seberapa baik tanaman tersebut dapat tumbuh. Tinggi tanaman pada rumput Mott disajikan dalam tabel 2.

Tabel 2. Rata-rata Tinggi Tanaman (cm) rumput Mott

\begin{tabular}{ccc}
\hline No & Perlakuan & Rata - rata \\
\hline 1 & P0 & $78,4^{\mathrm{a}}$ \\
2 & P1 & $76,4^{\mathrm{a}}$ \\
3 & P2 & $78,7^{\mathrm{a}}$ \\
4 & P3 & $79,2^{\mathrm{a}}$
\end{tabular}

Keterangan ; angka dengan superskrip huruf berbeda pada kolom yang sama menunjukkan perbedaan yang nyata $(\mathrm{p}<0,05)$

Rata-rata tinggi tanaman yang dihasilkan dalam penelitian ini adalah $\mathrm{P} 0=78,4 \mathrm{~cm}, \mathrm{P} 1$ $=76,4 \mathrm{~cm}, \mathrm{P} 2=78,7 \mathrm{~cm}$ dan $\mathrm{P} 3=79,2 \mathrm{~cm}$. Hasil analisa data pada tinggi tanaman menunjukkkan bahwa perlakuan jarak tanam yang berbeda tidak berpengaruh nyata $(P>0,05)$ terhadap tinggi tanaman rumput Mott. Rataan tinggi tanaman yang relatif sama tersebut diduga disebabkan oleh faktor pemupukan, bibit dan keadaan tanah yang sama.

Serupa dengan faktor yang mempengaruhi jumlah anakan bahwa ketersediaan unsur hara yang masih tersedia dalam keadaan cukup, menyebabkan pertumbuhan dan perkembangan rumput Mott pada fase vegetatif tidak berbeda pada defoliasi pertama. Sejalan dengan pernyatan Lasamadi (2013) bahwa unsur nitrogen (N) sangat besar kegunaannya bagi tanaman untuk pertumbuhan dan perkembangan, antara lain membuat daun tanaman lebih segar dan banyak mengandung klorofil yang mempunyai peranan sangat penting dalam proses fotosintesis, mempercepat pertumbuhan tanaman (tinggi, jumlah anakan dan lain-lain) serta menambah kandungan protein tanaman.

Dalam penelitian yang dilakukan, rumput Mott menghasilkan tanaman dengan kisaran tinggi 76,41 - 79,21 cm. Rataan tinggi tanaman rumput Mott saat penelitian lebih rendah dibandingkan hasil penelitian oleh Taulu \& Paulus (2012) yang berkisar $163-168 \mathrm{~cm}$. Namun hasil yang didapatkan dalam penelitian ini lebih baik dari yang diperoleh Sirait (2015) menyatakan dalam penelitiannya rumput Mott yang dihasilkan memiliki tinggi sekitar 36 $42 \mathrm{~cm}$.

\section{Panjang daun}


Tabel 3. Rata-rata Panjang Daun $(\mathrm{cm})$ rumput Mott

\begin{tabular}{ccc}
\hline No & Perlakuan & Rata - rata \\
\hline 1 & P0 & $53,7^{\mathrm{a}}$ \\
2 & P1 & $51,9^{\mathrm{a}}$ \\
3 & P2 & $53,5^{\mathrm{a}}$ \\
4 & P3 & $52,0^{\mathrm{a}}$
\end{tabular}

Keterangan ; angka dengan superskrip huruf berbeda pada kolom yang sama menunjukkan perbedaan yang nyata $(\mathrm{p}<0,01)$

Panjang daun rumput Mott hasil penelitian adalah $\mathrm{P} 0=53,7 \mathrm{~cm}, \mathrm{P} 1=51,9 \mathrm{~cm}, \mathrm{P} 2=$ $53,5 \mathrm{~cm}$ dan $\mathrm{P} 3=52 \mathrm{~cm}$. Hasil analisa sidik ragam perbedaan jarak tanam pada tabel 3 tidak berpengaruh nyata $(\mathrm{P}>0,01)$ terhadap panjang daun rumput Mott. Panjang daun pada penelitian ini berbeda dengan hasil penelitian oleh Sirait, Tarigan dan Simanihuruk (2015) menyatakan dalam penelitiannya panjang daun yang dihasilkan $43-60 \mathrm{~cm}$. Lasamadi, dkk (2013) juga menambahkan bahwa panjang daun dari penelitian yang dilakukannya $50-61$ $\mathrm{cm}$.

Kepadatan tanaman mempengaruhi tingkat produksi hijauan karena berpengaruh terhadap penyerapan cahaya matahari oleh tanaman yang diperlukan dalam proses fotosintesis. Hal ini didukung oleh pendapat Sawen (2012) faktor yang dibutuhkan dalam pertumbuhan adalah suplai air, cahaya dan hara. Cahaya matahari merupakan faktor iklim yang sangat penting dalam fotosintesis karena berperan sebagai sumber energi pembentuk tanaman. Gangguan yang timbul akibat kekurangan cahaya dapat dilihat dari bentuk penampilan pertambahan panjang dan lebar daun.

\section{Lebar daun}

Lebar daun berbanding lurus dengan panjang daun. Apabila daun bertambah panjang, lebar daun juga akan bertambah. Pengukuran lebar daun dilakukan pada semua daun dalam rumpun tanaman rumput Mott. Lebar daun rumput Mott pada defoliasi pertama disajikan dalam tabel 4 .

Tabel 4. Rata-rata Lebar Daun $(\mathrm{cm})$ rumput Mott

\begin{tabular}{ccc}
\hline No & Perlakuan & Rata - rata \\
\hline 1 & P0 & $2,3^{\mathrm{a}}$ \\
2 & P1 & $2,3^{\mathrm{a}}$ \\
3 & P2 & $2,4^{\mathrm{a}}$ \\
4 & P3 & $2,4^{\mathrm{a}}$
\end{tabular}

Keterangan ; angka dengan superskrip huruf berbeda pada kolom yang sama menunjukkan perbedaan yang nyata $(\mathrm{p}<0,05)$

Lebar daun rumput Mott hasil penelitian adalah $\mathrm{P} 0=2,3 \mathrm{~cm}, \mathrm{P} 1=2,3 \mathrm{~cm}, \mathrm{P} 2=2,4 \mathrm{~cm}$ dan $\mathrm{P} 3=2,4 \mathrm{~cm}$. Hasil analisa sidik ragam perbedaan jarak tanam pada tabel 4 tidak 
berpengaruh nyata $(\mathrm{P}>0,05)$ terhadap lebar daun rumput Mott. Hasil yang didapat dalam penelitian ini berbeda dengan yang dinyatakan oleh Sirait, Tarigan dan Simanihuruk (2015) yang menyatakan dalam penelitiannya lebar daun yang dihasilkan 2,8 $-3,7 \mathrm{~cm}$. Lasamadi, dkk (2013) juga menambahkan dalam penelitiannya lebar daun yang dihasilkan 2,6-3,2 cm.

Selaras dengan panjang daun, lebar daun pada tanaman juga dipengaruhi oleh intensitas cahaya yang didapatkan. Hal ini didukung oleh pendapat Sawen (2012) faktor yang dibutuhkan dalam pertumbuhan adalah suplai air, cahaya dan hara. Cahaya matahari merupakan faktor iklim yang sangat penting dalam fotosintesis karena berperan sebagai sumber energi pembentuk tanaman. Gangguan yang timbul akibat kekurangan cahaya dapat dilihat dari bentuk atau penampilan pertambahan panjang dan lebar daunnya.

\section{Berat segar}

Tujuan utama penanaman rumput adalah memperoleh berat segar yang maksimal. Berat segar merupakan akumulasi dari keseluruhan variabel yang dihitung pada saat pemanenan. Nilai pakan rumput dipengaruhi oleh umur potong, pada penelitian ini rumput Mott dipanen pada umur 55 hari setelah tanam.

Tabel 5. Rata-rata produksi Berat Segar (gram) rumput Mott

\begin{tabular}{ccc}
\hline No & Perlakuan & Rata - rata \\
\hline 1 & P0 & $566^{\mathrm{a}}$ \\
2 & P1 & $594^{\mathrm{a}}$ \\
3 & P2 & $612^{\mathrm{a}}$ \\
4 & P3 & $608^{\mathrm{a}}$
\end{tabular}

Keterangan ; angka dengan superskrip huruf berbeda pada kolom yang sama menunjukkan perbedaan yang nyata $(\mathrm{p}<0,05)$

Berat segar per unit tanaman/rumpun yang diperoleh dari hasil penelitian secara berturut adalah $\mathrm{P} 0=566$ gram, $\mathrm{P} 1=517$ gram, $\mathrm{P} 2=612$ gram dan $\mathrm{P} 3=608$ gram. Hasil penelitian menunjukkan bahwa secara statistik perbedaan jarak tanam rumput Mott tidak berpengaruh nyata $(\mathrm{p}>0,05)$ terhadap produksi berat segar per rumpun. Hasil berbeda didapatkan Taulu dan Paulus (2012) sekitar 3500 gram per rumpun. Paat dan Luice (2012) juga menambahkan bahwa dalam penelitiannya rumput Mott menghasilkan berat segar sekitar 4600 gram per rumpun.

Jarak tanam mempengaruhi tinggi rendahnya hasil tanaman, sehingga tinggi rendahnya hasil tanaman mempengaruhi produksi dalam satu areal. Peningkatan produksi diawali oleh meningkatnya hasil per satuan luas, kemudian setelah titik maksimum tercapai hasil akan menurun. Diduga jarak tanam mempengaruhi ketersediaan unsur hara bagi tanaman yang berperan dalam proses pertumbuhan dan perkembangan tanaman sehingga juga akan berpengaruh terhadap berat segar tanaman. Sari (2012) menyatakan produksi rumput dipengaruhi pertambahan tinggi dan jumlah anakan yang dihasilkan. Hal ini berbeda dengan pendapat Cristianto dan Agung (2014) menyatakan bahwa tingginya hasil per satuan luas tidak secara nyata didukung oleh pertumbuhan vegetatif tanaman. Banyaknya jumlah anakan tidak selalu menghasilkan produksi berat segar yang optimal.

\section{KESIMPULAN}


Jarak tanam tidak berpengaruh terhadap produktivitas rumput Mott. Akan tetapi walaupun hasil analisis tidak berbeda nyata akan tetapi kecenderungan pada jarak P2 $100 \mathrm{x}$ $100 \mathrm{~cm}$ memiliki hasil produksi lebih baik dari perlakuan lainnya.

\section{DAFTAR PUSTAKA}

Cristianto, H. Dan I G.A.M.S. Agung. 2014. Jumlah Bibit Per Lubang dengan Jarak Tanam Berpengaruh Terhadap Hasil Padi Gogo (Oryza Sativa L.) Dengan System Of Rice Intensification Di Lahan Kering. J. Bumi Lestari. 14 (11):1-8

Gazperzs, V. , 1991, Metode Rancangan Percobaan, Graha Mendia, Penerbit UI

Hatta, Muhammad. 2011. Pengaruh Jarak Tanam Terhadap Komponen Hasil Dua Varietas Padi Pada Metode Sri. Jurnal Floratek vol 6 : 104-113.

Khakim, Muhammad. 2017. Pengaruh Umur Bibit Dan Jarak Tanam Terhadap Pertumbuhan Dan Hasil Tanaman Padi (Oryza sativa L) Dengan Pola Tanam Sri ( System Of Rice Intensification). Jurnal Agroteknologi Merdeka Pasuruan 1(1) : 1-9.

Lasamadi R. D., Malalantang S. S, Rustandi dan Anis S. D. 2013. Pertumbuhan dan Perkembangan Pennisetum purpureun Cv. Mott yang Diberi Pupuk Organik Hasil Fermentasi EM4. Jurnal Zootek 32 (5): 158 - 171.

Muhaka, A. Nepoleon Dan P. Rosa. 2012. Pengaruh Pemberian Pupuk Cair Pada Rumput Gajah (Pennisetum purpureum.). Jurnal Peternakan Sriwijaya 1(1) : 48-54.

Nurlaili. 2010. Respon Pertumbuhan Tanaman Jagung (Zea Mays L.) Dan Gulma Terhadap Bebagai Jarak Tanam. Agronobis Vol. 2 (4): 19-29.

Paat, C. Paulus Dan Luice A. Taulu.2012. Introduksi Tanaman Pakan Unggul Penisetum purpureum Cv. Mott Di Sentra Produksi Sapi Potong Di Sulut. Seninar Nasional Teknologi Peternakan : 384 -391.

Sandiah, Natsir, Yulius B. dan La Ode S. 2011. Uji Keseimbangan Hara Dan Variasi Jarak Tanam Terhadap Pertumbuhan dan Produksi Rumput Gajah. Agriplus 21: 94-100.

Sari, Rica Mega. 2012. Produksi Dan Nilai Nutrisi Rumput Gajah (Pennisetum Purpureum) cv. Taiwan Yang Diberi Dosis Pupuk N,P,K Berbeda Dan CMA Pada Lahan Kritis Tambang Batubara. Padang : Universitas Andalas.

Sawen, Diana. 2012. Pertumbuhan Rumput Gajah (Pennisetum purpureum) Dan Benggala (Panicum maxicum) Akibat Perbedaan Intensitas Cahaya. Universitas Papua : Manokwari.

Seseray, Daniel Yohanis. Budi Santoso Dan Marlin Nelce Lekitoo. 2013. Produksi Rumput Gajah (Pennisetum Purpureum cv.Mott) Yang Diberi Pupuk N,P Dan K Dengan Dosis 0,50 Dan 100\% Pada Devoliasi Hari Ke-45. Sains Peternakan 11(1) : 49-55. 
Sirait, Juniar, Tarigan. A dan Simanihuruk. K. 2015. Karakteristik Morfologi Rumput Gajah Kerdil (Pennisetum Purpureum cv. Mott) Pada Jarak Tanam Berbeda Di Dua Agroekosistem Di Sumatra Utara. Prosiding Seminar Nasional Peternakan dan Veteriner : $643-649$.

Sulistya, A. T. dan Mariyono. 2013. Produktivitas Rumput Unggul Di Area Tambang. Seminar Nasional Teknologi Peternakan dan Veteriner : 455 - 460.

Thalib, Ibnul. 2016. Pertumbuhaan Rumput Gajah (Pennisetum Purpereum cv.Mott) Pada Berbagai Konsentrasimedia Murashige Dan Skoog Dengan Tehnik Kultur Jaringan. Makasar: Universitas Hassanudin. 